\title{
PROTEIN MARKERS USEFUL IN AUTHENTICATING Eurycoma longifolia CONTAINED HERBAL APHRODISIAC PRODUCTS
}

\author{
Jaya Vejayan*1, Venoos Iman $^{2}$, Foong Siew-Liang ${ }^{2}$ and Halijah Ibrahim ${ }^{2}$ \\ ${ }^{1}$ Quest International University Perak, 227, Jalan Raja Permaisuri Bainun 30250 Ipoh, Perak Darul \\ Ridzuan. \\ ${ }^{2}$ Institute of Biological Sciences, University of Malaya, 50603 Kuala Lumpur, Malaysia. \\ * Corresponding author (Quest International University Perak, 227, Jalan Raja Permaisuri Bainun 30250 \\ Ipoh, Perak Darul Ridzuan. E-mail: jayavejayan@yahoo.com)
}

\begin{abstract}
Eurycoma longifolia has been widely recognized for its aphrodisiac benefits and many herbal products incorporated with its extract been sold worldwide. The products in various forms of capsules or spherical tablets were appropriately solubilized in water and their protein content were separated using two dimensional electrophoresis (IPG strip of pI 3-10; 15\% homogenous gel) and stained in coomassie blue. In this study using a standardized extract known for its biological activity, CFPR-JV1, two distinctive protein markers were detected within $2 \mathrm{DE}$ gel. The markers were spots found approximately at molecular weight of $14 \mathrm{kDa}$ at the basic extremities. The markers were not detected in a selected herbal product devoid of Eurycoma longifolia extract. In screening markers on a total of 23 National Pharmaceutical Control Bureau (NPCN) approved and 6 NPCB un-approved products claimed to have included Eurycoma longifolia extracts gave results with 18 of the 29 (approximately 62\%) products observed with the presence of at least marker A, while the rest did not show presence of any markers. This enabled authentication of the products tested related to its active constituent. It is expected that the protein markers in addition to the existing chemical marker, Eurycomanone, may serve to be useful in authenticating genuine, unadulterated or sufficiently enough amount of Eurycoma longifolia in herbal aphrodisiac products.
\end{abstract}

\begin{abstract}
ABSTRAK Tongkat Ali telah diiktiraf secara meluas bagi faedah perangsang seksualnya dan banyak produk-produk herba yang digabungkan dengan ekstrak herba ini telah dijual di seluruh dunia. Produk dalam bentuk kapsul atau tablet sfera yang pelbagai sesuai dilarutkan dalam air dan kandungan protein mereka telah dipisahkan menggunakan jel dua dimensi (jalur IPG pI 3-10; $15 \%$ jel homogenus) dan diwarna dengan coomassie biru. Dalam kajian ini suatu ekstrak yang sebelum ini telah diiktiraf mengandungi aktiviti biologi iaitu ekstrak CFPR-JV1 telah dikesani dengan dua penanda protein melalui teknik jel 2DE. Penanda-penanda berkenaan adalah pada lokasi kira-kira berat molekul 14kDa dan pada kawasan beralkali. Penanda-penanda protein ini tidak dikesan dalam produk herba yang diiktiraf tidak mempunyai ekstrak Tongkat Ali. Dalam saringan penanda di dalam sejumlah 23 produk kategori lulusan Biro Kawalan Farmaseutikal Kebangsaan (NPCN) serta 6 produk dalam kategori tidak pernah diluluskan oleh NPCN tetapi mendakwa menagandungi ekstrak Tongkat Ali memberi keputusan cerakinan iaitu 18 daripada 29 (kira-kira 62\%) produk dikesani dengan kehadiran sekurang-kurangnya dengan penanda A, manakala yang lain tidak menunjukkan kehadiran kedua-dua penanda. Pengesahan ini membolehkan produk-produk tersebut diujikesan dengan juzuk yang aktif. Oleh yang demikian adalah dijangkakan penanda protein selain penanda kimia yang sedia ada iaitu Eurycomanone, berguna dalam mengesahkan kesahihan kehadiran ekstrak Tongkat Ali dalam pelbagai produk herba afrodisiak.
\end{abstract}

(Keywords: plant, aphrodisiac, standardization, two dimensional electrophoresis, protein)

\section{INTRODUCTION}

Eurycoma longifolia from the family Simaroubaceae is a medium sized shrub that is endemic to Southeast Asia[1]. The locals identify it by the common name 'Pasak Bumi' or 'Tongkat Ali' and it has been long recognized as an herbal plant with several medicinal values.
The root extract is believed to be an aphrodisiac which enhance male virility and sexual prowess. The plant extract (particularly roots) have been used in indigenous traditional medicines for its unique antimalarial, anti-pyretic, antiulcer, cytotoxic and aphrodisiac properties [2-6]. The aphrodisiac property of $E$. longifolia was confirmed by various studies done on male rats [7-15]. 
The aphrodisiac power of E. longifolia has been harnessed and commercialized with estimates of nearly 200 products, mainly highlighting the aphrodisiac properties, are available in the health-food market [5]. Since it is widely acknowledged by people all around the world, the demand for E. longifolia supplements especially those in the form of capsules and tablets are hence, worldwide [16]. Extracts of this herb have often been incorporated in some natural body building supplements due to the positive effect of this plant on testosterone production. Recently, it has been effectively marketed as an aphrodisiac and a natural libido enhancer that can help many middle aged men to retrieve their youthful appetite [17]. The amount of extract used in each tablet is vital as low concentrations are ineffective. This can be overcome if the extraction and preparation processes are standardized, however this is not the case and therefore, it remains questionable whether every product still retain enough of the bioactive constituent of E. longifolia. This is especially true for products that are not approved by any pharmaceutical authoritative bodies. We suspect that these clandestine "cottage" industries which lack quality control might produce products that do not contain $E$. longifolia root extract at all or that the unsubtle processing methods might damage its pharmaceutical properties. Counterfeit drugs have recently become a serious problem all over the world where products are deliberately mislabeled, added with the wrong ingredient, wrong amount of ingredient or with no active ingredient at all [18].

The Malaysian National Pharmaceutical Control Bureau (NPCB) requires for approval purposes all herbal product manufacturers to submit information that include the manufacturing process, material specifications, quality control of raw material and test data. Even after that, the products are constantly under post marketing surveillance in which chemical tests are performed on random samples. Tests conducted by both manufacturers and NPCB include those that check its pharmaceutical content, heavy metal content ( $\mathrm{As}, \mathrm{Pb}, \mathrm{Cd}$ and $\mathrm{Hg}$ ), triterpenes and steroid content, weight uniformity and microbial contamination[19]. Despite the stringency, it remains elusive whether NPCB validate or has the mean to validate the aphrodisiac property of the products. Although a microcontroller-based taste system had been invented to discriminate between liquids that contain E. longifolia extract and those that are not, the invention detects various different chemical components of the liquid and not its bioactive aphrodisiac component. [20] Many unique organic molecules and quassinoids such as eurycomanone, eurycomanol, eurycomaoside etc have been identified [16, 21], but it has been determined that the aphrodisiac bioactive component of $E$. longifolia is a peptide that has been patented by the name Eurypeptide [22-23]. The results of an earlier research based on collaboration between MIT-FRIM linked the active components of E. longifolia to be protein based as well [24]. As such in this current study proteomics technology (conventional method for protein characterization) was used to investigate potential protein markers that can be used to authenticate some E. longifolia contained products in the market.

\section{MATERIAL AND METHODS}

\section{Test materials}

E. longifolia capsules of different brands were obtained from various pharmacies and drug stores in peninsular Malaysia. Some products are sold online to international customers. These products are classified into two groups, those that are approved by NPCB (coded as MON-A01 - MON-A23) and the others that are not (coded as MON-X01 - MON-X06). All approved products are attached with a NPCB hologram sticker while the unapproved ones are not. The name, brand and the manufacturer of the capsules are not shown to protect the anonymity of the products. For products that come in the form of capsules, the shells were physically removed and the powdery content was stored. For spherical tablets, they were crushed by using mortar and pestle until they became powdery. CFPR-JV1 and MON-JV1 were used as positive controls while MON-NC which contains Smilax myosotiflora extract instead of E. longifolia was used as negative control. CFPR-JV1 is a standardized E. longifolia root extract obtained from Forest Research Institute Malaysia (FRIM) while MON-JV1was extracted in our own laboratory. Its extraction is as follows, initially, $50 \mathrm{~g}$ of E. longifolia root chips were boiled with $600 \mathrm{ml}$ of deionized distilled water in a round bottom flask attached to a condenser for 5 hours. Then, the condensed liquid was filtered before being freeze dried for the final powdery products. All MON-JV1 extracted samples were kept at $-20^{\circ} \mathrm{C}$. 


\section{Two Dimensional Gel Electrophoresis (2DE)}

The protein content in each sample was quantified by using Bradford protein quantification assay. The first dimensional run; Isoelectric focusing (IEF) was then performed on rehydrated Immobiline ${ }^{\mathrm{TM}}$ Drystrip $\mathrm{pH}$ 3-10NL, $7 \mathrm{~cm}$ IPG strips (GE Healthcare) with the sample loaded by using a sample cup. Prior to this, the correct amount of sample with $25 \mu \mathrm{g}$ protein content was mixed with $250 \mu \mathrm{l}$ of rehydration buffer containing $8 \mathrm{M}$ urea, $2 \%$ (w/v) CHAPS, 20mM DTT (dithiothereitol), $1 \%$ (v/v) IPG buffer and $0.002 \%(\mathrm{w} / \mathrm{v})$ Bromophenol Blue. The order of parameters used during IEF run were step and hold at $200 \mathrm{~V}$ for 1 hour, gradient at $1000 \mathrm{~V}$ for 1 hour, gradient at 5000 for 4 hours and finally step and hold at $5000 \mathrm{~V}$ for 1 hour. After IEF, the IPG strips were equilibrated twice on a rocking table with buffer containing $50 \mathrm{mM}$ Tris/ $\mathrm{HCl}, 6 \mathrm{M}$ urea, $30 \%$ (v/v) glycerol, $2 \%$ SDS and a trace of Bromophenol Blue with addition of $30 \mathrm{mM}$ DTT for the first time and $70 \mathrm{mM}$ iodoacetamide for the second time, 10 minutes each. The second dimensional run; polyacrylamide gel electrophoresis (PAGE) was performed thereafter. The equilibrated strips were loaded onto a $15 \%$ polyacrylamide gel (9.6 cm length $X 8.2 \mathrm{~cm}$ width) and the electrophoresis run was initiated at $250 \mathrm{~V}$ until the dye front reached the bottom of the gel. The separated gel proteins were visualized by Coomassie Brilliant Blue staining. They were then scanned by a digital scanner and saved in tagged image file format (TIFF).

Another modified 2DE run was also performed whereby MON-A07 was "spiked" with the positive control, CFPR-JV1. This was done by introducing the two samples separately using two loading cups onto a rehydrated IPG strip during IEF run as described in previous works [25-27].

\section{Data analysis}

Scanned gel pictures were analyzed using Bio Rad'sPDQuest 2D Analysis Software. The image was automatically rendered into grayscales by the software in order for it to perform further analysis on the picture. The background noise was filtered out using Gaussian filtering method. Once filtered, the area expected to have the markers were analyzed using the software's 3D viewer to confirm the marker's peaks.

\section{RESULTS}

\section{Markers and their validation}

In both positive controls, CFPRJV1 and MONJV1, two prominent and reproducible spots were detected approximately at molecular weight of $14 \mathrm{kDa}(15 \%$ homogenous gel) at basic extremities of a 3-10 IPG strip [Fig. 1(a) and (b)]. The gels were only stained with coomassie blue as attempts to stain with silver staining method failed to show any spots (results not included). Negative control, MON-NC, though showed other spots but not the markers [Fig. 1 (c)]. Figure 1 also showed two products been screened for presence of markers, A and B, with MON-A15 having them [Fig 1 (d)] while none observed in MON-A09 [Fig. 1(e)].

Another validation method that was performed in this study was "spiking". One of the samples was loaded separately with positive control, CFPRJV1 onto the same IPG strip. The amount of proteins loaded from each cup was $25 \mu \mathrm{g}$. If the proteins of interest from the tested samples had similar charge and molecular size with the positive control, the two dimensionally separated protein markers should be more pronounced and slightly larger in size. Taking MON-A07 as a representative, its protein sample was spiked with positive control CFPR-JV1. After spiking, the markers are significantly more distinct. The 3D representation shows visibly higher peaks for both the markers, thus validating them (Fig 2). Besides that, it also shows that spiking is a reliable method to confirm that protein spots from two different samples are of same protein origin.

In a total of 23 NPCB approved samples that have been tested, 14 showed the presence of marker A while 13 for marker B (Table 1). MON-A06 was the only sample which showed the presence of marker A but not marker B. While for the six samples that were unapproved by NPCB only MON-X04 and MON-X06 were found to have none of the markers present. MON-A10 which showed a negative result for both markers was actually devoid of E. longifolia extract according to the ingredient description even though it is labeled as a 'Tongkat Ali' herbal product. Hence, a total of 14/23 ( 61\%) of the NPCB approved products in comparison to $4 / 6(\sim 67 \%)$ of the unapproved NPCB products showed the presence of marker A. Overall 
approximately $62 \%$ of the total products showed presence of marker(s).
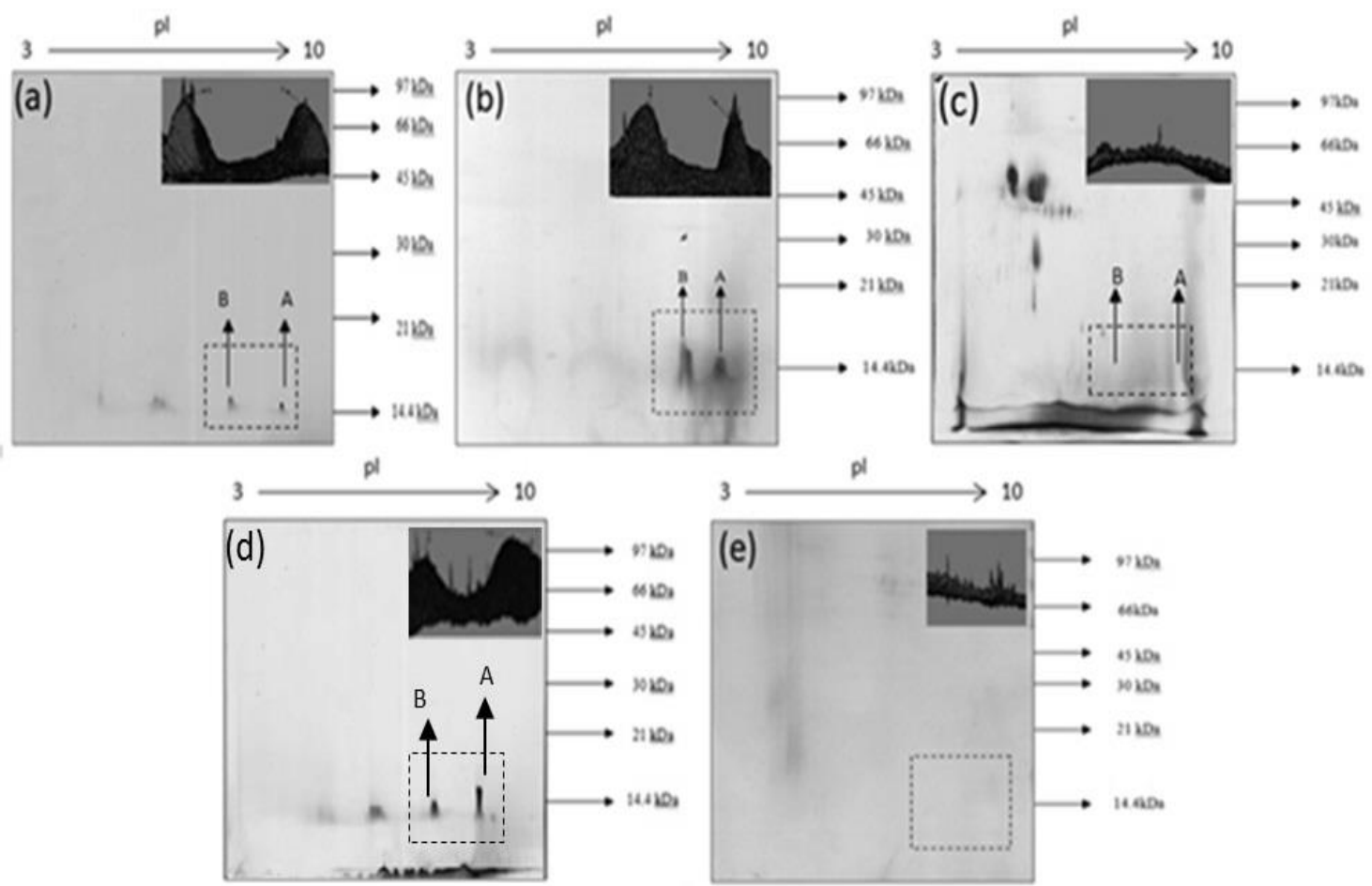

Figure 1. 2DE on (a) CFPRJV1 (positive control), (b) MON-JV1 (positive control), (c) MON-NC (negative control), (d) MON-A15 (product with both markers detected) and (e) MON-A09 (product with no markers). Insert on upper right corner showing 3D view obtained using Bio Rad's PDQuest.

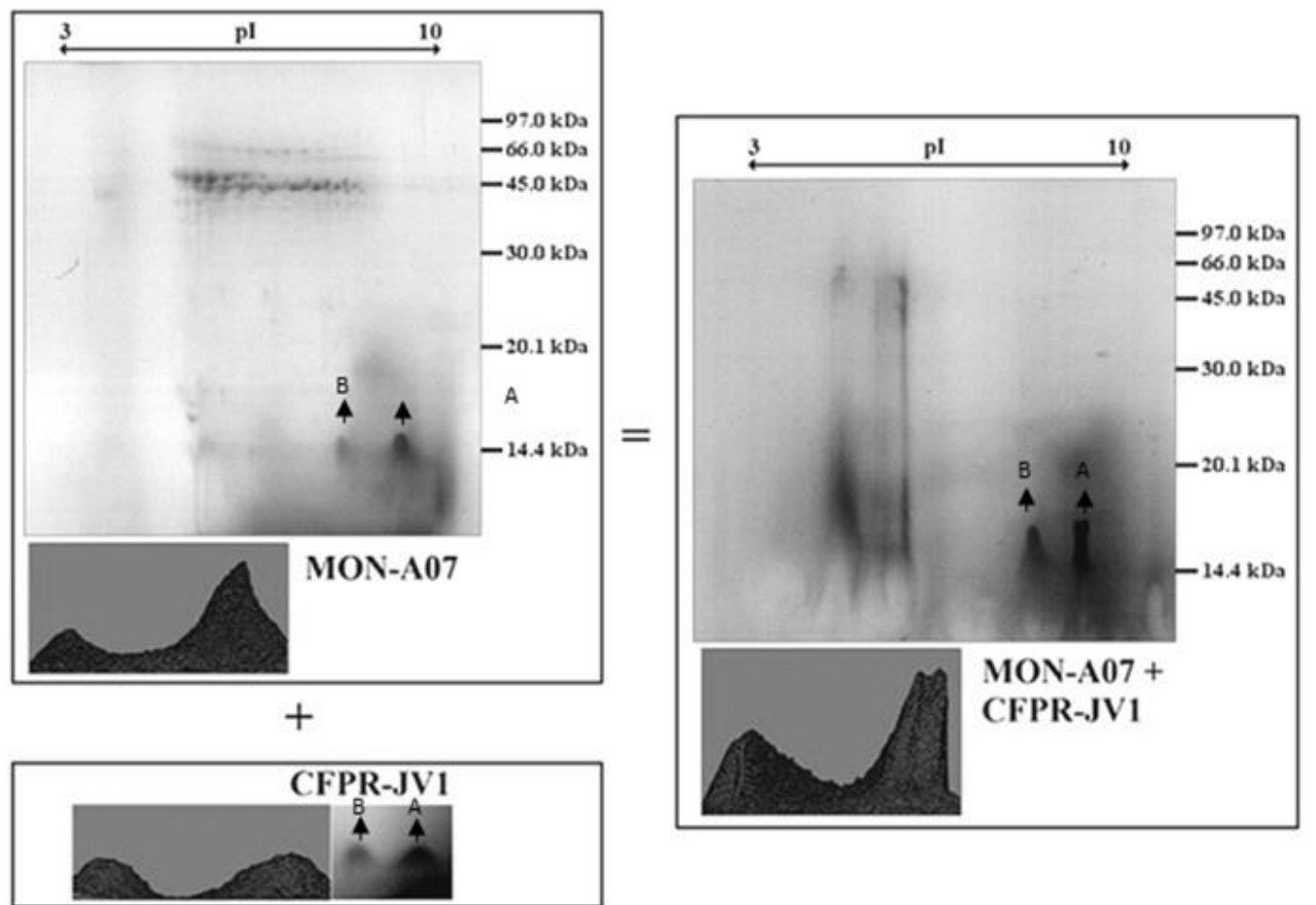

Figure 2. The stained gel images and the corresponding 3D representations of CFPR-JV1, MON-A07 and spiking of CFPR-JV1 with MON-A07. 
Table 1. The presence $(\boldsymbol{V})$ or absence $(\boldsymbol{X})$ of protein markers A and B in each tested samples.

\begin{tabular}{|c|c|c|c|c|c|}
\hline No & Sample & $\begin{array}{l}\text { Protein } \\
\text { content } \\
(\mu \mathrm{g} / \mathrm{mg} \\
\text { sample) }\end{array}$ & Product content $(\%)$ & $\begin{array}{l}\text { Marker } \\
\text { A }\end{array}$ & $\begin{array}{l}\text { Marker } \\
\text { B }\end{array}$ \\
\hline 1 & MON-A01 & 1.5162 & $100.0 \mathrm{EL}$ & $x$ & $x$ \\
\hline 2 & MON-A02 & 2.7439 & $\begin{array}{l}\text { 40.0 EL; } 20 \text { Tinospora cordifolia stem extract; } 20.0 \\
\text { Glycyrrhiza glabra root extract; } 20.0 \text { Centella asiatica } \\
\text { herb extract }\end{array}$ & $\checkmark$ & $\checkmark$ \\
\hline 3 & MON-A03 & 3.1967 & $\begin{array}{l}\text { 8.6 EL; } 17.2 \text { Herbs Epimedium brevicornum; } 17.2 \\
\text { Actinolitum ; } 17.2 \text { Cuscuta chinensis; } 17.2 \text { Cynomorium } \\
\text { songaricum; } 13.8 \text { Semen Cuscuta chinensis; } 8.6 \text { Herb } \\
\text { Cistannche deserticola }\end{array}$ & $x$ & $x$ \\
\hline 4 & MON-A04 & 8.1172 & $\begin{array}{l}\text { 68.1 EL; Semen } 1.9 \text { Pimpinella anisum; } 4.2 \text { Semen } \\
\text { Cumimum cymimum; } 1.9 \text { Rhizome Zingiber officinale; } \\
\text { 1.9 Sticepus variegahus; } 1.9 \text { Sticepus variegahus; } 1.9 \\
\text { semen Piper nigrum; } 1.9 \text { Semen Piper nigrum; } 1.2 \text { Semen } \\
\text { Coriandrum sativum; } 4.0 \text { Rhizoma Alpinia golango; } 6.7 \\
\text { Radix Curcuma zedoaria; } 4.2 \text { Garlic oil macerate. }\end{array}$ & $\checkmark$ & $\checkmark$ \\
\hline 5 & MON-A05 & 2.1419 & 60.0 EL; 40.0 Radix Astragali seu hedysari. & $\checkmark$ & $\checkmark$ \\
\hline 6 & MON-A06 & 5.6404 & $\begin{array}{l}\text { 15.6 EL; } 21.9 \text { Rhizoma Smilax } \\
\text { myosotiflora; } 15.6 \text { Rhizoma Allomorphia malacensis; } 4.7 \\
\text { Semen Trigonella foenum graecum; } 7.8 \text { Rhizoma } \\
\text { Zingiber minus; } 7.8 \text { Caulis Leptosmermum flavescens; } 4.7 \\
\text { Rhizoma Acorus calamus; 9.4 Semen Nigella sativa; } 4.7 \\
\text { Semen Coriandrum sativum; } 4.7 \text { Fructus Piper longum; } \\
\text { 3.1 Semen Trachyspermum ammi. }\end{array}$ & $\checkmark$ & $x$ \\
\hline 7 & MON-A07 & 5.2864 & $\begin{array}{l}\text { 85.0 EL; } 10.0 \text { Semen Nigella sativa; } 5.0 \text { Folium Cassia } \\
\text { angustifolia. }\end{array}$ & $\checkmark$ & $\checkmark$ \\
\hline 8 & MON-A08 & 11.284 & $\begin{array}{l}\text { 24.0 EL; } 20.0 \text { Nigella sativa; } 10.0 \text { Globia Pendula; } 2.0 \\
\text { Curcuma domestica; } 10.0 \text { Piper nigri fructus; } 10.0 \\
\text { Languas galangal; } 24.0 \text { Foeniculum vulgare. }\end{array}$ & $\checkmark$ & $\checkmark$ \\
\hline 9 & MON-A09 & 4.4613 & $\begin{array}{l}\text { 20.0 EL; } 40.0 \text { Fructus Saw palmetto Power extract; } 10.0 \\
\text { Pumpkin Seed Powder Extract; } 10.0 \text { Fructus Tribulus } \\
\text { terrestris powder extract; } 20.0 \text { Root Muria puama powder } \\
\text { extract. }\end{array}$ & $x$ & $x$ \\
\hline 10 & MON-A10 & 4.3800 & $\begin{array}{l}\text { 0.0 EL, 21.5 Herbs Coriondrum sativum; } 4.4 \text { Radix } \\
\text { Smilax myositiflora; } 4.3 \text { Herb Pimpenella anisum; } 4.3 \\
\text { Herbs Cuminum cyminum; 4.3 Seed Nigella sativa; } 4.3 \\
\text { Rizom Alpinia galanga; 3.2 Rizom Curcuma domestica; } \\
\text { 33.4 Honey; 3.1 Sesame oil; } 3.2 \text { Rizom Zingeber } \\
\text { officinale; 4.3 Flos Eugenia aromatica; } 2.2 \text { Helicteres } \\
\text { isora; } 2.2 \text { Fructus Myristica fragrans; } 2.2 \text { Seed Piper } \\
\text { nigrum; 3.2 Semen Tracchyspermum ammi. }\end{array}$ & $x$ & $x$ \\
\hline 11 & MON-A11 & 6.9000 & $\begin{array}{l}\text { 16.0 EL; } 30.0 \text { Angullia angullia; } 20.0 \text { Radix Striga } \\
\text { asiatica; } 14.0 \text { Zingiber officinale rhizome; } 10.0 \text { Radix } \\
\text { Smilax myositiflora zingiber; } 10.0 \text { Bulbus Allium sativum. }\end{array}$ & $\checkmark$ & $\checkmark$ \\
\hline 12 & MON-A12 & 7.0200 & $\begin{array}{l}\text { 14.6 EL; } 29.3 \text { Honey; } 20.5 \text { Bean oil; } 2.9 \text { Rhizoma } \\
\text { Zingiber officinale; 0.4 Flos Eugenia aromatica; } 5.9 \\
\text { Herba piper nigrum; } 2.9 \text { Herba Croton caudatum; } 4.4 \\
\text { Herba Coriandrum sativum; } 1.5 \text { Herba Nigella sativa; } 1.5 \\
\text { Fructus Pimpinella anisum; } 1.5 \text { Stichopus variegatus; } \\
\text { 14.6 Morinda citrifolia. }\end{array}$ & $x$ & $x$ \\
\hline 13 & MON-A13 & 2.2700 & 100.0 EL. & $\checkmark$ & $\boldsymbol{V}$ \\
\hline
\end{tabular}




\begin{tabular}{|c|c|c|c|c|c|}
\hline 14 & MON-A14 & 5.0500 & $\begin{array}{l}\text { 25.6 EL; 25.6 Maca extract/Rhizoma Lipidum meyenii; } \\
\text { 25.6 American Ginseng extract; } 23.3 \text { Ginkgo biloba } \\
\text { powder. }\end{array}$ & $x$ & $x$ \\
\hline 15 & MON-A15 & 1.5500 & $100.0 \mathrm{EL}$ & $\checkmark$ & $\checkmark$ \\
\hline 16 & MON-A16 & 2.4670 & $\begin{array}{l}70.0 \text { EL; } 10.0 \text { Radix Achyranthes bindentata; } 10.0 \text { Cortex } \\
\text { Eucommia ulmoides; } 10.0 \text { radix Astrogalus } \\
\text { membranaceus bge. }\end{array}$ & $\checkmark$ & $\checkmark$ \\
\hline 17 & MON-A17 & 8.1090 & $\begin{array}{l}\text { 51.2 EL; } 2.1 \text { Euginia caryaphylata Fructus; } 4.3 \text { Radix } \\
\text { Curcuma zedoaria; } 4.3 \text { Zingiber officinale roscope; } 2.5 \\
\text { Rhizome Cuminum cyminum; } 2.1 \text { Semen Piper nigrum; } \\
2.1 \text { Rhizome Alpina galangal; } 4.3 \text { Semen Pimpinella } \\
\text { anisum; } 1.3 \text { Semen Cariandrum sativum; } 12.0 \text { Semen } \\
\text { Nigella sativa; } 12.0 \text { Cortex Cinnamomum zeylanicum; } 1.8 \\
\text { Fructus Myristica fragrans. }\end{array}$ & $x$ & $x$ \\
\hline 18 & MON-A18 & 6.2360 & $\begin{array}{l}\text { 1.0 EL; 2.0 Piper Longum fructus; } 1.0 \text { Helicteres isora } \\
\text { stem; } 96.0 \text { Coriandrum sativum seed. }\end{array}$ & $\checkmark$ & $\checkmark$ \\
\hline 19 & MON-A19 & 4.5000 & $\begin{array}{l}10.0 \text { EL; } 30.0 \text { Stem Ardisia crispa; } 20.0 \text { Stem } \\
\text { Cinnamoum iners; } 20.0 \text { Radix Moringa elliptica; } 5.0 \\
\text { Rhizome Smilax myositiflora; } 5.0 \text { Stem Alyxia } \\
\text { reinwardtii; } 5.0 \text { Stem Alyxia indica; } 5.0 \text { Radix } \\
\text { Freycinetia malaccensis. }\end{array}$ & $x$ & $x$ \\
\hline 20 & MON-A20 & 7.1860 & $\begin{array}{l}11.3 \text { EL; } 17.5 \text { Herba Cynomorium songaricum; } 16.3 \\
\text { Semen Cuscuta chinensis; } 12.5 \text { Cortex Eucommia } \\
\text { ulmoides; } 12.5 \text { Radix Panax ginseng; } 11.3 \text { Fructus } \\
\text { Tribulus terrestris; } 10.0 \text { Rhizoma Dioscorea opposite } ; 8.8 \\
\text { Fructus Lycium barbarum. }\end{array}$ & $\checkmark$ & $\checkmark$ \\
\hline 21 & MON-A21 & 6.8950 & $\begin{array}{l}\text { 42.9 EL; } 28.6 \text { Eleuthercoccus senticosus root extract; } 28.6 \\
\text { Fructus Tribulus terrestris extract. }\end{array}$ & $x$ & $x$ \\
\hline 22 & MON-A22 & 5.5640 & $100.0 \mathrm{EL}$ & $\checkmark$ & $\checkmark$ \\
\hline 23 & MON-A23 & 3.6560 & $100.0 \mathrm{EL}$. & $\sqrt{ }$ & $\sqrt{ }$ \\
\hline 24 & MON-X01 & 2.5896 & $100.0 \mathrm{EL}$. & $\checkmark$ & $\checkmark$ \\
\hline 25 & MON-X02 & 2.7273 & 50.0 EL; 50.0 Ginseng. & $\sqrt{ }$ & $\checkmark$ \\
\hline 26 & MON-X03 & 2.1210 & $100.0 \mathrm{EL}$. & $\sqrt{ }$ & $\sqrt{ }$ \\
\hline 27 & MON-X04 & 0.3734 & $\begin{array}{l}\text { 15.0 EL; 5.0 Extract Miristica fragrans; } 10.0 \text { Extract } \\
\text { Yohimbin; } 20.0 \text { Zingiber rhizome; } 30.0 \text { Curcuma } \\
\text { zedoaria; } 20.0 \text { Other ingredients. }\end{array}$ & $x$ & $x$ \\
\hline 28 & MON-X05 & 0.8069 & $\begin{array}{l}\text { 40.0 EL; } 10.0 \text { Pantrocinum; } 10.0 \text { Syngnathoides } \\
\text { biaculeatus; } 10.0 \text { Panax Ginseng radix; } 10.0 \text { Yohimbehae; } \\
\text { 10.0 Ganoderma; } 10.0 \text { Hypocampus. }\end{array}$ & $\checkmark$ & $\checkmark$ \\
\hline 29 & MON-X06 & 2.5567 & $100.0 \mathrm{EL}$, flower seeds and herbs. & $x$ & $x$ \\
\hline
\end{tabular}

\section{DISCUSSION}

The markers are found in the region of low molecular weight of approximately $14 \mathrm{kDa}$ and distinctively to be at the basic site which is often being vertically streaked. The marker spots were only detected in coomassie and not in silver staining. These staining dyes are known to have far less sensitivity i.e leading to weak staining or even failure of detection when used for detection of highly glycosylated proteoglycans (proteinglycosaminoglycans) or glycoproteins (protein- oligosaccharides) [28-29]. Additionally this also suggested the markers to be glycopeptides based on its low molecular weight and its heat stability. Many reports linked, though not conclusively, the aphrodisiac activity to be glycopeptide in nature [22 - 24]. Our attempts to determine their identity by LC MS/MS (results not included) failed as the protein database available in Mascot for E. longifolia was only four proteins, which were related to photosynthetic mechanism rather than linked to aphrodisiac activity [30]. In any case the de novo sequencing done on the 
significant ions revealed amino acid sequence that may aid in primer designs for further work.

In most cases the markers are the only spots detected due to the extraction process requiring boiling causing protein denaturation. This has been the norm in traditional extraction as well as in most modern techniques whereby chips of the dried roots been boiled in water for hours to yield extracts supposedly having the aphrodisiac activity [31]. Nevertheless two dimensional electrophoresis of some extracts were shown to have other spots present as well for e.g. MonA07 (Fig 2). As the labels of the products do not indicate clearly the extraction process utilized this observation of having certain products showing numerous spots still remains unclear. It must be noted that even if the sample size for the unapproved products were relatively small due to the difficulties in obtaining them, the detection of the markers in them is quite admirable. As such it is likely the efficacy of these unapproved products might match or are better than the approved ones. Nevertheless there are still risks of other contaminants (fungi or bacteria or heavy metals) which are supposed to be strictly regulated by NPCB. The reason why most unapproved products contain the biomarkers is due to the fact that E. longifolia extract can be obtained easily with little processing. This was demonstrated by the positive results obtained with MON-JV1 extracted in our laboratory.

Spot A appears as the definite marker as it is found present in all extracts labeled to contain $E$. longifolia extracts. Marker A was also noticed to be more prominent and conspicuous than spot B. Hence we suggested the use of this spot as a quality control marker during the testing in batch production of these herbal products at the manufacturing site. Agency such as NPCB may incorporate this marker apart from the existing Eurycomanone in their enforcing activities [3233]. The latter has been clearly indicated as not being the constituent responsible for the aphrodisiac activity. In the wake of many fake $E$. longifolia products with some even been adulterated with drugs like sildenafil citrate or acetildenafil sold mostly over the internet, a thorough testing involving multiple techniques with specific markers such as ours is certainly required [34]. The surplus in fake products in the US market had even the US FDA got concerned [35-36].

\section{CONCLUSION}

The increasing number of herbal products relevant to aphrodisiac benefits claimed to have incorporated $E$. longifolia extracts is on an alarming rise with various scrupulous activities detected in similar extend. A thorough and specific authentication is warranted using marker A detected in two dimensional electrophoresis, a subset of proteomics technology.

\section{ACKNOWLEDGEMENT}

This work was completed by a grant provided by University Malaya. We thank FRIM for providing the positive control, CFPR-JV1 and Miss Suraya Hamid for extracting E. longifolia root extract (MON-JV1) in our laboratory.

\section{REFERENCES}

1. Samy J, Sugumaran M \& Lee KLW. (2005) Herbs of Malaysia, Selangor, Malaysia, Times Edition.

2. Gimlette JD. (1977) A Dictionary of Malayan Medicine. In: THOMSON JW (ed.). Kuala Lumpur, Malaysia: Oxford University Press.

3. Perry LM, Metzger J editors. (1980) Medicinal plants of East and Southeast Asia: attributed properties and uses. MA, USA: Massachusetts Institute of Technology Press, 389.

4. Ismail Z, Ismail N, Lassa J. (1999) Malaysian herbal monograph; Malaysian Monograph Committee, Kuala Lumpur.

5. Jagananth JB, Ng JB (2000). Herbs the green pharmacy of Malaysia. Vinpress Sdn. Bhd. and Malaysian Agricultural Research and Development Institute (MARDI), Kuala Lumpur, Malaysia, 45-6.

6. Bhat R, Karim, AA. (1997) Tongkat Ali (Eurycoma longifolia Jack): A review on its ethnobotany and pharmacological importance. Fitoterapia, 81: 669-79.

7. Ang HH \& Sim MK. (1997) Eurycoma longifolia Jack enhances libido in sexually experienced male rats. Exp 
Anim

46:

287-90.

8. Ang HH, Sim MK. (1998a) Eurycoma longifolia increases sexual motivation in sexually naive male rats. Arch Pharm Res. 21: 779-81.

9. Ang HH, Sim MK. (1998b) Eurycoma longifolia Jack and orientation activities in sexually experienced male rats. Biol Pharm Bull. 21: 153-5.

10. Ang HH, Cheang HS, Yusof AP. (2000) Effects of Eurycoma longifolia Jack (Tongkat Ali) on the initiation of sexual performance of inexperienced castrated male rats. Exp Anim. 49: 35-8.

11. Ang HH, Ngai TH. (2001) Aphrodisiac evaluation in non-copulator male rats after chronic administration of Eurycoma longifolia Jack. Fundamental \& Clinical Pharmacology. 15: 265-68.

12. Ang HH, Ikeda S, Gan EK. (2001) Evaluation of the potency activity of aphrodisiac in Eurycoma longifolia Jack. Phytother Res. 15: 435-6.

13. Ang HH, Lee KL. (2002) Effect of Eurycoma longifolia Jack on orientation activities in middle-aged male rats. Fundam Clin Pharmacol. 16: 479-83.

14. Ang HH, Ngai TH, Tan TH. (2003) Effects of Eurycoma longifolia Jack on sexual qualities in middle aged male rats. Phytomedicine. 10: 590-3.

15. Wahab NA, Mokhtar NM, Halim WN, Das S. (2010) The effect of Eurycoma longifolia Jack on spermatogenesis in estrogen-treated rats. Clinics (Sao Paulo). 65: 93-8.

16. Bedir E, Abou-Gazar H, Ngwendson JN, Khan IA. (2003) Eurycomaoside: a new quassinoid-type glycoside from the roots of Eurycoma longifolia. Chem Pharm Bull (Tokyo). 51: 1301-3.

17. Jarvie P. (2011) Asian Live Longer by Boosting Testestrone with Tongkat Ali. http://ezinearticles.com/?Asians-LiveLonger-by-Boosting-Testosterone-
With-Tongkat-Ali\&id=5989004. Accessed on 29.2.2013.

18. Jackson G, Arver S, Banks I, Stecher VJ. (2010) Counterfeit phosphodiesterase type 5 inhibitors pose significant safety risks. Int J Clin Pract. 64: 497-504.

19. Drug Registration Guidance Document 2013 of National Pharmaceutical Control Bureau (NPCB), Ministry of Health, Malaysia. (2013). Available from:

http://portal.bpfk.gov.my/index.cfm?\& menuid=99. Accessed on 31.1.2013.

20. Rahman ASA, Yap MMS, Shakaff AYM, Ahmad MN, Dahari Z, Ismail Z, Hitam MS. (2004) A microcontrollerbased taste sensing system for the verification of Eurycoma longifolia. Sensors and Actuators B: Chemical. 101: 191-198.

21. Darise M, Kohda H, Mizutani K, Tanaka O. (1982) Eurycomanone and eurycomanol, quassinoids from the roots of Eurycoma longifolia. Phytochemistry. 21: 2091-93.

22. Asiah O, Nurhanan MY, Ilham, MA. (2007). Determination of bioactive peptide $(4.3 \mathrm{kDa})$ as an aphrodisiac marker in six Malaysia plants. $J$ Tropical Forest Sci. 19: 3.

23. Tambi MI. (2009) Nutrients and Botanicals for optimizing Men's Health. Examining the evidence for Eurycoma longifolia jack, the Malaysian Ginseng in men's health. Asian J Androl. 11: 2.

24. Sambandan TG, Chokyun R, Kadir AA, Aminudin N, Johar MS. (2004) Bioactive fraction of Eurycoma longifolia. United State Patent, Patent No: US7132, 117B2.

25. Vejayan J, Tang MS, Ibrahim H. (2012) The Role of Conventional TwoDimensional Electrophoresis (2DE) and Its Newer Applications in the Study of Snake Venoms In Joshua L. Heazlewood and Christopher J. Petzold, Subject editors: Tsz-Kwong Man, 
Ricardo J. Flores (Eds. ), Proteomic Applications in Biology (pp.225-52). InTech [Accessed from http://www.intechweb.org/books/show/t itle/proteomic-applications-in-biology].

26. Tang MS, Vejayan J, Ibrahim $\mathrm{H}$. (2011). The Concept of TwoDimensional Electrophoresis-Guided Purification Proven by Isolation of Rhodocetin from Calloselasma rhodostoma (Malaysian Pit Viper). J Venom Anim Toxins incl Trop Dis. 17: 442-450.

27. Vejayan J, Ibrahim H, Othman I. (2008) Locating alpha-bungarotoxin in 2-DE gel of Bungarus multicinctus (many banded krait) venom. Malays J Sci. 27: 8.

28. Harvey A, Goldberg, Warner KJ. (1997). The Staining of Acidic Proteins on Polyacrylamide Gels: Enhanced Sensitivity and Stability of "StainsAll" Staining in Combination with Silver Nitrate. Analytical Biochemistry. 251: 227-33.

29. Møller HJ, Poulsen JH. (2009) The Protein Protocols Handbook Springer Protocols Handbooks. pp 569-574, 3rd edition and edited by John M. Walker.

30. National Center for Biotechnology Information (NCBI) software. (2013). Available from: http://www.ncbi.nlm.nih.gov/protein/?te $\mathrm{rm}=$ Eurycoma+longifolia. Accessed on 31.1.2013.

31. Athimulam A, Kumaresan S, FOO DCY, Sarmidi, MR, Aziz, RA. (2006) Modelling and optimization of Eurycoma Longifolia water extract production. Institution of Chemical Engineers Trans IChemE, Part C, Food and Bioproducts Processing. 84: 139 149.

32. Chan KL. (2004) Recent advances in research on Tongkat Ali. In: Chang YS, Mastura M \& Nurhanan MY (Eds). In the Proceedings of the Seminar on Medicinal Plants. 20-21 August 2002. Tongkat Ali, Kacip Fatimah \& Pegaga.
New Dimensions In Complementary Healthcare. 11.

33. Hassan NH, Abdullah R, Kiong LS, Ahmad AR, Nazirah. (2012) Micropropagation and production of eurycomanone, 9-methoxycanthin-6one and canthin-6-one in roots of Eurycoma longifolia plantlets African Journal of Biotechnology. 11: 6818-25.

34. Becoat WC. Access Financial Market. (2006). Available from: http://www.fda.gov/ICECI/Enforcement Actions/WarningLetters/2005/ucm0759 81.htm. Accessed on 31.1.2013.

35. Rawlings K. FDA Warns Consumers About Dangerous Ingredients in "Dietary Supplements" Promoted for Sexual Enhancement. (2006). Available from:

http://www.fda.gov/NewsEvents/Newsr oom/PressAnnouncements/2006/ucm10 8690.htm. Accessed on 31.1.2013.

36. FDA Consumer Health Information. (2009). Available from: http://www.fda.gov/ForConsumers/Con sumerUpdates/ucm048386.htm. Accessed on 31.1.2013. 